\title{
The prevention of workplace bullying as a question of human resource management: measures adopted and underlying organizational factors
}

\author{
Denise Salin \\ Forthcoming in Scandinavian Journal of Management ${ }^{1}$
}

The aim of this study has been to analyze measures adopted to counteract workplace bullying from the perspective of human resource management. First, the kind of measures that are adopted to prevent bullying were examined. Second, factors affecting the extent of such measures were explored. The introduction of written anti-bullying policies and the provision of information were found to be the most common measures adopted. The policies strongly emphasized the role of supervisors and the immediate superior. Measures to counteract bullying were positively related to the adoption of 'sophisticated' human resource practices, previous negative publicity concerning bullying and the presence of a young human resource manager. The results, however, also indicated that imitation seemed to provide an important impetus behind anti-bullying efforts.

Key words: bullying; harassment; human resource management; policies; prevention; public sector

\section{Introduction}

Over the last twenty years or so, interest in analyzing negative interactions in the workplace has been on the increase (cf. Einarsen, Hoel, Zapf \& Cooper, 2003). The present article analyzes organizational measures adopted to counteract one particular form of negative and

${ }^{1}$ If you want to cite this article before publication please cite it as: Salin, D. The prevention of workplace bullying as a question of human resource management: measures adopted and underlying organizational factors, Scandinavian Journal of Management (2008), doi: 10.1016/j.scaman.2008.04.004 
counterproductive interaction at work, namely workplace bullying. A human resource management perspective has been adopted.

Bullying is a form of negative interaction that can express itself in many ways, ranging from verbal aggression and excessive criticism or monitoring of work to social isolation or silent treatment (cf. Einarsen et al., 2003). Typically, it is thus a question of the accumulation of many 'minor' acts, amounting to a pattern of systematic maltreatment. It differs from ordinary 'conflict' since there is generally a victim-perpetrator configuration, such that the person on the receiving end feels unable to defend him or herself successfully (e.g. Einarsen \& Skogstad, 1996; Vartia, 1996). Nonetheless, bullying is not restricted to tyrannical types of leadership behaviours; it can also occur among colleagues at the same hierarchical level or even upwards, i.e. when subordinates bully a manager. This is because perceived power imbalances may not arise only from organizational hierarchy: they can arise from other individual, situational or societal characteristics, as well. Perceived power or powerlessness may thus be influenced, for example, by access to knowledge and expertise, by support from influential persons, by dependence on others or by gender-based stereotypes (cf. Cleveland \& Kerst, 1993; Einarsen et al., 2003).

Over the last twenty years or so, several studies have appeared on the consequences of bullying. The uniform view seems to be that bullying in the workplace can have severe detrimental consequences both for the victims and for the organizations concerned (e.g. Hoel, Einarsen \& Cooper, 2003; Mikkelsen \& Einarsen, 2002). A number of studies have also been conducted on individual and organizational antecedents (for summaries see Salin, 2003; Zapf \& Einarsen, 2003). Despite all this, and apart from some advice about how to deal with bullying in the workplace (e.g. Hubert, 2003; Mathieson, Hanson \& Burns, 2006; Richards \& Daley 2003; Vartia, Korppoo, Fallenius \& Mattila, 2003), hardly any empirical research has been conducted about the kind of measures used by organizations to combat bullying.

Moreover, we know very little about the role of Human Resource (HR) managers or other HR professionals in preventing workplace bullying. In fact, one of the few articles to address bullying and human resource management investigated whether the very adoption of HR management rather than 'traditional personnel management' might not be a possible 
cause of reported increases in bullying (Lewis \& Rayner, 2003). ${ }^{2}$ Human resource management is thus described as potentially exacerbating bullying, rather than preventing it. The literature on workplace bullying has evolved separately from that of HR, although two recurrent themes in the bullying literature have been that (1) violations of employee dignity and well-being may have severe negative effects on work performance (e.g. Hoel et al., 2003) and that (2) bullying is closely linked to other organizational and managerial practices such as work organization, reward systems and leadership (e.g. Salin, 2003).

The HR literature reveals an emphasis on practices that have been described as 'high performance work practices' (e.g. Huselid, 1995) or 'sophisticated' HR practices (Heffernan \& Flood, 2000). These practices include such things as extensive training, the use of formal performance appraisal and regular employee attitude surveys. However, although employee dignity and well-being are typically regarded as a subject for the personnel or human resources function, we know nothing about the relative character or effects of a general emphasis on 'sophisticated' HR practices on the one hand and more specific efforts to prevent workplace bullying on the other. Further, although the HR manager is likely to have considerable influence over any formal measures to prevent workplace bullying, the extent to which characteristics of this manager - age, gender, education and so on - have any effect on whether or not organizations impose any preventive measures has not been examined.

The aims of the present study are thus to analyze organizational action against bullying, and to explore the factors that affect the extent of any anti-bullying measures that are undertaken. In addition, the contents of anti-bullying policies are analyzed in some detail. The study was conducted in Finnish municipalities. The Finnish context was particularly interesting, since a new Occupational Safety and Health Act (2002) came into force in

\footnotetext{
${ }^{2}$ Lewis and Rayner (2003) discuss the key elements of HRM as outlined by Storey (1993). These include 1) the belief that the commitment of employees, rather than their mere compliance, is needed to provide a competitive edge, 2) that HRM has a strategic, rather than a mere welfare role to play, and 3) that since human resources are seen as critical to the success of organizations, the role of line mangers in managing issues traditionally handled by personnel specialists increases.
} 
January 2003, including an explicit requirement that employers should take action in cases of 'harassment and other inappropriate treatment' in the workplace. This has been generally interpreted as an 'anti-bullying' clause.

\section{Preventing workplace bullying}

\section{Organizational antecedents of workplace bullying}

Before recommending ways to prevent workplace bullying, we need a thorough understanding of the factors associated with an increasing risk of bullying. During the last twenty years or so a number of studies have been conducted on the individual and organizational antecedents of bullying (cf. Salin, 2003; Zapf \& Einarsen, 2003). The main results concerning the organizational antecedents - which are under management control to a greater extent than other kinds - will be summarized below to provide a basis for discussing potential preventive action. Organizational factors that have been identified as potential risk factors include leadership, work organization and job design, and organizational culture and social climate.

The connection between leadership and the prevalence of bullying has been studied extensively and several forms of destructive leadership behaviour have been identified (e.g. Einarsen, Aasland \& Skogstad, 2007). Abusive supervision (Tepper, 2000) or tyrannical leadership (Einarsen et al, 2007) can sometimes themselves represent a form of bullying. But laissez-faire leadership behaviour can also be destructive (Skogstad, Einarsen, Torsheim, Aasland \& Hetland, 2007), by allowing bullying to escalate. This has also been demonstrated in a number of empirical studies (Einarsen, Raknes \& Matthiesen, 1994; Hoel \& Cooper, 2000), which confirm a relation between high levels of bullying and laissez faire leadership behaviours.

Several other factors connected with job design and work organization have also been suggested as possible factors behind bullying. Examples include the absence of clear goals (Vartia, 1996), organizational constraints, lack of control over one's own job (Einarsen et al., 1994; Vartia, 1996), and role conflict or ambiguity (Einarsen et al., 1994). 
A third set of factors that affect the prevalence of bullying is connected with organizational culture and the social climate in an organization. Robinson and O'Leary-Kelly (1998) and Collinson (1988) have demonstrated the impact of role models and the kind of culture that celebrates toughness and encourages humiliating 'jokes' while failing to discourage 'inappropriate treatment'. A poor social climate, marked by envy, competition and cliquebuilding has also been shown to be a risk factor (Vartia, 1996).

A number of organizational factors may contribute in various ways to the presence of workplace bullying. Salin (2003), for example, argues that whereas some factors enable bullying by reducing the cost to the perpetrator and by creating the perceived power differentials necessary for its accomplishment, others actually provide incentives or act as precipitating or triggering factors for bullying activities. The risk for bullying can thus be analyzed applying a danger-effect ratio (cf. Björkqvist, Österman \& Lagerspetz, 1994), that is to say, the perpetrator is likely to assess the potential risk associated with engagement in bullying and the potential benefits to be gained from it. If bullying is to be prevented, it is thus important both to raise the cost, i.e. the risk of being discovered and reprimanded, and to reduce the incentives. It is important to make things quite clear regarding the responsibility attaching to the job and the appropriate behaviour expected, to demonstrate by word and deed that bullying is not to be accepted, and to increase managers' capabilities to detect bullying and address it when it does occur.

\section{Prevention of workplace bullying}

It has been noted that organizational factors play an important part in either 'allowing' or 'disallowing' bullying to take place. In order to reduce bullying it is thus necessary to address the factors that might enable bullying, and try instead to disenable it, perhaps by increasing the perceived cost to the perpetrator or by supporting satisfaction and clarity in general (see Figure 1).

In order to engender 'zero-tolerance' for bullying, to increase general awareness of what is involved and to clarify what is meant by 'appropriate' work behaviour, researchers and practitioners have both recommended the introduction of specific anti-bullying policies 
(European Agency, 2002; Hubert 2003; Mathieson et al., 2006; Richards \& Daley, 2003; Vartia et al., 2003). Despite a few minor differences in details, researchers seem to agree on certain core issues that should be covered in such a policy (e.g. European Agency, 2002; Richards \& Daley, 2003). These include an explicit commitment to a bullying-free environment, a definition of the kinds of behaviour that are regarded as bullying and those that are not, together with a statement of the consequences of breaching the organizational standards. Richards and Dailey (2003) also emphasize the importance of clarifying the responsibility borne by the various actors involved, identifying specific contact persons and explaining the procedure for making and investigating informal and formal complaints.

However, for an anti-bullying policy to be successful the text itself - i.e. the very existence of a written statement about the unacceptability of bullying and recommended procedures against it - is not enough. Thus, the process of developing and applying the policy is at least as important as its actual contents. Richards and Daley (2003) emphasize the importance of incorporating staff from all levels and union representatives in the process of developing and implementing the policy, since broad involvement is needed to emphasize the status of the process, and to increase awareness and acceptance of it throughout the organization. Vartia et al. (2003) stress that anti-bullying policies are not only important for the victims of bullying; they also provide managers with guidelines and advice about how to deal with bullying, which in turn may make them more willing and more competent to react appropriately.

Since weak leadership and failure to assume responsibility in cases of interpersonal conflict have both been identified as major risk factors (e.g. Einarsen et al., 1994; Hoel \& Cooper, 2000), any action taken to increase leader competence in dealing with bullying is of the utmost importance. The inclusion of skills in identifying and dealing with bullying and interpersonal conflicts in management training is thus generally recommended as a way of reducing bullying. Although managers play a crucial part in dealing with bullying, more awareness and knowledge of bullying at all levels is also important so that situations that could escalate into bullying can be quickly identified. Increased awareness may also encourage employees to combat it, either by refusing to take part directly or by refusing to watch silently. That people should be given information about bullying - its forms, its causes and consequences - is thus a point that is stressed in most guidelines. 
Furthermore, early intervention is important. This means getting prompt information about unacceptable behaviour. Mathieson et al. (2006) regard checking the environment and monitoring the staff as an important factor in the prevention strategy. Informal and formal appraisal discussions with staff and regular employee surveys can thus provide useful information and help to ensure early intervention.

Thus, overall, a number of recommendations for preventing workplace bullying have been suggested. However, little has been done to check whether organizations actually follow these recommendations. Some recent studies of the connection between various organizational factors and the prevalence of workplace bullying have found a negative relationship between prevalence on the one hand and the existence of an anti-bullying policy and information provision on the other (Baillien, Neyens, DeWitte \& Vanoirbeck, 2005; Moreno-Jimenez, Rodríguez-Muñoz, Garresa \& Morante, 2005). Apart from this, however, little attention has been paid to the characteristics or the efficacy of organizational measures in the relevant research. The aim of the present paper is thus to focus on the first of these factors. The extent to which the recommendations provided in literature are followed will be examined. In addition, factors that affect the extent of any anti-bullying measures that are taken are explored.

\section{Method}

\section{Design of the study and characteristics of the sample}

This study was designed as a survey, and a questionnaire was sent to all the municipalities (431) in Finland. The study was carried out in the spring of 2006, i.e. fully three years after the implementation of the new Occupational Health and Safety Legislation in Finland, in which harassment and other inappropriate treatment are explicitly mentioned. The survey design was chosen to enable a representative overview of the situation in Finnish municipalities, and the design allowed for contacting all municipalities. The questionnaire was developed on the basis of a preliminary study, which had been conducted by a student and supervised by the present author (Storgårds, 2006). The preliminary study consisted of interviews in five public sector organizations. Municipalities were chosen in preference to 
private organizations, since the preliminary study had found that this kind of information was disclosed more readily in the public sector than in the private. The slightly greater prevalence rates reported for bullying in the public as opposed to the private sector in Finland also made the public sector a relevant choice (Salin, 2001).

The survey was conducted on-line, and a short description of the study and a link to an online survey was e-mailed to all respondents. The person in charge of HR/personnel matters in every municipality was identified and the link to the questionnaire was sent to this person’s e-mail address.

After two reminders had been sent, a total of 205 responses were received, which meant a response rate of $47.6 \%$. All the regions in Finland, and municipalities of all sizes, were represented among the replies. The median for number of employees was 400 , with $8.7 \%$ of the responding municipalities having less than 100 employees and 20.5\% having 1000 employees or more. Of the respondents, $81.8 \%$ held a degree from a university or a polytechnic. There were slightly more female respondents (54\%), which is not surprising given that the public sector and personnel work are both often characterized as female arenas for work in Finland.

\section{Research instrument}

The questionnaire consisted of questions regarding action taken and background information about the municipality, and can be obtained from the author upon request.

Preventive measures. Respondents were asked about the existence of written anti-bullying policies, whether information or training about bullying had been provided to employees, whether surveys on bullying had been conducted, and whether the number of bullying cases reported had been statistically recorded. In all cases the respondents could choose between 'yes', 'no', and 'don't know'. For the question about anti-bullying policies, respondents could also choose 'no, but being planned at the moment'. To indicate the systematic character of the anti-bullying activities, the numbers of the respective measures undertaken by the individual municipalities were registered on a scale (0-5). For municipalities currently lacking an anti-bullying policy but planning one, a score of 0.5 was added. A 
separate question as to whether or not general work climate surveys had been carried out ('yes'/'no'/'don't know') was also included in the questionnaire, but this was not considered in the index.

Size of municipality. Respondents were asked to report the number of employees in the municipality.

Negative publicity. Respondents were asked to rate the volume of negative publicity concerning bullying received on a scale from 1 (none) to 5 (a great deal).

Performance of municipality. Respondents were asked to rate subjectively seven indicators of municipal performance on a scale from 1 (very low) to 5 (very high). The indicators included perceived economic performance, future prospects, service level and employee well-being and Cronbachs' alpha for this scale was 0.74 (for a discussion on the use of subjective measures of performance see e.g. Wall, et al., 2004).

Characteristics of the HR Manager (or other person in charge of HR/personnel matters). Again, respondents were asked to indicate their sex and their age. Originally respondents were asked to give their age as under 35,35 to 50 , or over 50 . As very few proved to be under 35, replies were collapsed into two groups: 50 and under, and over 50. As regards level of education, respondents were given several alternatives ranging from elementary school to university. As most respondents had reached a high level of education, the replies were collapsed into two groups: those with and those without university/polytechnic degrees.

Use of 'sophisticated' human resource practices. The extent to which what could be regarded as 'sophisticated' human resource practices or 'high performance work practices' were in use was measured by asking respondents to indicate the share (\%) of the personnel that was affected by certain HR practices typically regarded as 'sophisticated' (e.g. Heffernan \& Flood, 2000; Huselid, 1995). The four practices chosen for the present study were the use of employee attitude surveys, formal appraisal systems or appraisal 
discussions $^{3}$, performance-based pay and formal training (within the past two years). Cronbach's alpha for this measure of the presence of sophisticated HR practices was 0.50. The relatively low internal consistency can be explained by the fact that this is an example of a composite scale in which the indicators actually define and form the construct, rather than simply reflecting a common construct, i.e. the items are not interchangeable indicators of a single underlying construct (cf. MacKenzie, Podsakoff \& Jarvis, 2005; also see Edwards \& Bagozzi, 2000).

Open-ended questions. At the end of each section of the questionnaire, respondents were able to make additional comments or to add any information they considered relevant. Further, at the end of the section on various preventive measures (which included policy, training, information, and surveys), an open-ended question was added about possible additional measures. The replies were used not for statistical analysis, but simply as illustrative material.

\section{Analysis of anti-bullying documents}

The questionnaires sent to the respondents were accompanied by a request for copies of any written anti-bullying policies, to be sent either by e-mail or by regular post. By searching the municipalities' web pages or using Google search, the author was able to locate some additional municipal anti-bullying policies. Altogether this resulted in 27 anti-bullying policy documents.

Several aspects of the policies were selected for analysis. These included their design and layout, i.e. their length and professionalism, and their contents, i.e. how closely they followed the usual recommendations for anti-bullying policies. As regards content,

\footnotetext{
${ }^{3}$ Many organizations in Finland have introduced a system of semi-formal or formal appraisal discussions, where the employee and his or her immediate supervisor meet annually to discuss past performance and future goals and development needs. In Finnish the term 'kehityskeskustelu' is used, in Swedish 'utvecklingssamtal' (i.e. literally 'development discussion'). This may or may not be accompanied by more formal performance reporting.
} 
particular attention was also paid to the way bullying was framed and defined and what recommendations were made regarding victims and managers.

\section{Results}

\section{Preventive measures taken}

The review of earlier literature on workplace bullying revealed that typical recommendations for the prevention of bullying included the possession of an anti-bullying policy, the provision of training and information, and monitoring of the work climate by surveys and other methods.

The results of the present study showed that a majority of the responding municipalities (55.6\%) had introduced a written anti-bullying policy. A further $16.1 \%$ reported that the municipality was working on the development of such a policy. Most of the municipalities (65.9\%) had provided some form of information about bullying to employees and/or to managers. Over a quarter (27.3\%) said that they had provided training on the subject. Responding to open-ended questions, several respondents also emphasized how important it is to include bullying and its prevention in leadership training for managers and supervisors:

The prevention of such problems accords with the city personnel policy and is linked to the implementation of the personnel strategy. In a leadership training module on personnel management, the question of identifying the problem and the importance of early intervention are noted.

(Table 1 about here)

Changes in job design and work organization were also mentioned by several respondents in answering the open questions. Such changes were seen as additional useful strategies for preventing bullying, harassment and other forms of inappropriate treatment at work.

Appraisal discussions are held with staff at irregular intervals. This year [i.e. in 2006] all employees have been involved in a project, aimed at developing and strengthening the image of the organization both internally and externally. Themes have included 
[defining] role division and responsibility, higher quality and greater efficiency, positive work attitudes and job satisfaction, motivation and well-being at work, and fresh ideas for the future.

When it came to monitoring the work environment, $80.5 \%$ of the respondents reported that work climate surveys had been conducted, and 33.7\% noted that bullying issues had been explicitly included in work-climate surveys or in other specific surveys of bullying. In their additional comments several respondents also stressed the importance of monitoring and reporting progress in formal or informal discussions between staff and managers, and of trying to gauge the potential risks and thus allow for prompt intervention.

Over the past two years, such appraisal discussions have come to cover also harassment and inappropriate treatment at work.

The advantage of a small municipality is that it is possible to deal with problems promptly and to start looking for solutions.

It is also important to remember that only a quarter of the organizations (24.9\%) confirmed that the reported cases of bullying are statistically recorded. Thus, any future reporting of 'increases' or 'decreases' in the number of cases is not actually possible, nor is it likely to become so in the immediate future.

\section{Exploring differences in the extent of the preventive action}

The previous section presented data on the extent to which various anti-bullying measures were applied in Finnish municipalities. The next step was to examine how far these measures were part of a systematic attempt to prevent bullying or whether they represented disparate instances of such attempts. Thus, the number of measures listed in Table 1 that each municipality had adopted was counted and a 'prevention of bullying index', ranging from 0 to 5 , was created $(M=2.15, S D=1.29)$.

First, differences as regards various characteristics of the HR managers were explored. Municipalities with HR managers aged over $50(M=2.02, S D=1.27)$ reported a somewhat lower mean than municipalities whose HR managers were younger $(M=2.36, S D=1.32)$, 
$t(199)=1.88, p=0.06$. No differences were found with respect to the gender of the HR managers: for females $(M=2.19, S D=1.39)$, for males $(M=2.13, S D=1.19) t(196)=$ $0.313, p=0.76$. As regards educational level of the HR managers, the number of preventive measures in municipalities whose HR managers held a degree from a university or polytechnic was slightly higher $(M=2.21, S D=1.26)$ than in those whose managers did not hold such a degree $(M=1.92, S D=1.41)$, but this difference, too, was not significant $t(203)=-1.334, p=0.18$.

After conducting t-tests of the characteristics of the HR manager, correlations between the number of preventive measures taken and the scale variables were analyzed (see Table 2). The variables included number of employees, use of 'sophisticated' HR practices, the performance of the municipality and negative publicity about bullying. The results showed that measures to prevent bullying were positively correlated with the number of employees $(p<.01)$, the use of 'sophisticated' HR practices $(p<.01)$ and negative publicity concerning bullying $(p=.04)$. The analyses also showed that the number of employees was positively correlated with the use of 'sophisticated' HR practices $(p=.03)$, indicating that large municipalities were more likely to adopt advanced HR practices such as formal appraisal systems/appraisal discussions, performance-related pay, attitude surveys and training.

(Table 2 about here)

Finally, in order to assess the predictive power of the independent variables indicated above, a stepwise multiple regression analysis was conducted. The independent variables included number of employees, use of 'sophisticated' HR practices, negative publicity, performance of the municipality, and the age, gender and education of HR manager (the last three ones coded as dummy variables), while the dependent variable was the number of preventive measures taken. In this stepwise procedure three of the variables - use of 'sophisticated' HR practices, negative publicity and age of the HR manager - were included in the regression equation because of their contribution to the model. This model explained $16.8 \%$ of the variance in the number of preventive measures adopted. Due to the correlation between the number of employees and the use of 'sophisticated' HR practices, the former did not qualify for inclusion in the procedure. 
(Table 3 about here)

\section{Written anti-bullying policies}

To get a better idea of the measures taken against bullying in organizations, the 27 antibullying policy documents submitted by the HR managers or found on the municipalities' web site were analyzed. The first part of the analysis concerned the physical appearance of the documents. They ranged in length from 2 to 16 pages and consisted of anything from Microsoft Word memos to professionally printed brochures. However, further analysis of the contents indicated that the format of the brochure seemed to depend primarily on the size of the municipality, i.e. on the resources available, rather than on the content or depth of the material.

As to the content, particular emphasis was placed on the way bullying was framed and defined, and on the recommendations given to victims, perpetrators and managers. The terminology varied as regards the title and the content of the policies. Typical titles ran roughly as follows: 'Policy for the prevention of bullying/harassment in Municipality X'. Some, however, were framed in more positive terms such as 'Happiness at work is everyone's due', 'Let's be human' or 'Encouraging good work behaviour'. These tended to adopt a broader perspective on the issue of workplace bullying, regarding its prevention as part of good interpersonal relations at the workplace in general, and providing examples of good work practice.

Almost all the written documents included a definition of bullying (or 'harassment and inappropriate treatment') and provided both work-related and non-work-related examples of the phenomenon. The vast majority also clarified what was not to be regarded as workplace bullying. Only a few of the policy documents explicitly specified the potential perpetrators of bullying, although a closer reading suggests that superiors and colleagues are the typical perpetrators, and in some cases it was acknowledged that a superior could also be bullied by a subordinate.

Around three-quarters of the documents included an explicit statement of the unacceptability of bullying behaviour in that particular municipality, while about half 
explicitly mentioned potential disciplinary action. One factor common to all the documents was the inclusion of advice to the victims of bullying and to the managers regarding what they could do. In all the documents the victims were told first to talk to the harasser personally and to make it quite clear that they themselves found the behaviour offensive. It was sometimes further suggested that this action should be repeated in the presence of a colleague if the first remonstrance had not had any effect. The targets of bullying were then asked to contact their immediate superior (or if the superior was the bully, then the superior's superior). Managers were instructed to examine cases by 'hearing the parties' and 'collecting facts', but generally speaking little guidance was given about how to do this. Often the policy also mentioned other people who could be approached, either by a victim of bullying or an investigating manager. These included occupational health care services, health and safety delegates or union representatives, for example. However, individuals were seldom identified by name, nor was there any other information about how to contact them. There was usually no mention of the HR/personnel management department. Moreover, typically no advice was given to employees accused of bullying others.

In terms of content, the most striking impression lay in the similarity between many of the policy documents. Although it is understandable that similar practices are recommended in different municipalities, a closer analysis of the content showed that many documents actually used identical sentences and paragraphs. This applies not only to the section on defining what is and what is not bullying, but also to the sections on recommendations to the victims and to managers.

\section{Discussion}

This study has analyzed organizational measures for combatting workplace bullying in the context of human resource management. A relatively large number of the organizations that responded to the survey had taken action on the lines generally recommended in the bullying literature. In terms of the content of anti-bullying policies, respondents generally seem to have followed the relevant recommendations fairly closely (cf. Richards \& Daley, 2003). 
In municipalities with young HR managers anti-bullying measures were more common, which might reflect greater awareness of interpersonal issues among those who have received their education recently. However, it is interesting to note that the educational level or gender of the HR managers did not have a significant effect. Although some studies (e.g. Salin, 2007) have suggested that women are more likely to see bullying as an organizational problem, while men are more inclined to emphasize characteristics of the victims, this was not reflected in the action taken by female and male HR managers to prevent bullying.

The results showed that more steps had been taken to prevent bullying in large municipalities where 'sophisticated' HR practices - formal appraisal systems/appraisal discussions, performance-based pay, training and attitude surveys - were in use. This might suggest that greater emphasis on personnel issues in general is also associated with greater awareness of workplace bullying, as well.

The positive correlation between the number of preventive measures undertaken and the negative publicity about bullying seems to suggest that anti-bullying action is often undertaken in response to problems reported, rather than as a preventive measure. In other words, many municipalities may have introduced anti-bullying measures as part of a reactive rather than a proactive strategy. An alternative explanation could be, however, that anti-bullying measures raise employees' expectations of being treated with respect and dignity and therefore may make them more likely to report cases of bullying - either internally in the organization or externally to the media, for instance. Longitudinal data would be needed to establish which explanation is the more likely.

Overall, the survey did not find any very strong connections between organizational factors and the measures taken. However, the analysis of the written policy documents suggested a possible explanation for this. Although many of the policy documents included most of the issues mentioned in the various recommendations, the appearance of identical sentences and paragraphs in many of them was very noticeable. This may mean that best practices are being shared and spread. But it could also mean that adopting and formulating written antibullying policies is often a question of imitation, i.e. 'copy-paste', rather than a process driven by an organization's own needs and circumstances. Moreover, the sections that 
would require the most tailoring to the organizational circumstances - like naming contact persons or describing investigation procedures - were the ones that were most often missing, which further supports this assumption. Merely imitating what other organizations do and write, rather than thoroughly investigating the organization's own needs and resources and getting support from broad participation all along the line may mean that people are less committed, less aware of the policies and lacking the detail needed to address bullying successfully in a particular work environment (cf. Richards and Daley, 2003). Thus, a policy that is not adapted to the specific organizational context is less likely to be implemented and less likely to be effective if it is applied when bullying actually occurs.

On a more general level it would be extremely interesting to know who the HR managers or others responsible for anti-bullying strategies share their experiences with, and who they learn from. As this study has been limited to the public sector, it would also be interesting to see whether this imitation process occurs only between municipalities, or whether - and if so, how much - it also occurs between the public and the private sectors. Future studies should also investigate whether membership of a professional body for HR managers affects the managers’ willingness to take action against bullying.

One point worth noting is that in the written anti-bullying policies the HR department was seldom portrayed as a centre of support and advice either for the victims of bullying or for the managers concerned. Instead, victims were advised to contact their immediate superiors. Lewis and Rayner (2003) have pointed out that since it is typical of human resource management - as compared to traditional personnel management - that personnel issues are often passed down to the line manager level (cf. Storey, 1993), there are further difficulties for employees being bullied by their own supervisor. In addition, this further exacerbates the problem of managers who rely on a laissez-faire leadership style (cf. Skogstad et al., 2007 on the 'destructiveness' of laissez-faire leadership behaviour). Although the HR function may play an important part in formulating policy and procedures, it seems to lack the 'welfare function’ of traditional personnel management (cf. Lewis \& Rayner, 2003). 
Previous studies of bullying have already referred to the lack of evaluations of various prevention and intervention strategies (Di Martino, Hoel \& Cooper, 2003). A similar lack has been noted in the case of research on sexual harassment (cf. Bingham \& Scherer, 2001). The present study has revealed that only one in four of the municipalities had recorded any statistical information on the number of bullying cases reported, which makes it difficult for them to evaluate the effects of any policies or changes in policy. If there is no hard data on the number of cases over time, it is difficult to make an objective evaluation of any effects. Instead, any attempt to evaluate the effects of new measures will have to rely on the perceptions of change in the prevalence of harassment among certain key informants. But subjective perceptions of this kind risk being influenced by random patterns in the prevalence or by the high visibility of certain individual cases.

When analyzing results it is important to bear in mind the context in which a particular study has been undertaken, i.e. in the present case in the Finnish municipal sector. Although municipalities and joint municipal authorities together employ approximately one-fifth of Finland's total employed labour force, the great majority of their employees work within a few specific fields. More than $80 \%$ of them are engaged in education or in health and social care (see e.g. Commission for Local Authority Employers, 2007), and several studies have indicated particularly high rates of bullying in just these fields (Zapf, Einarsen, Hoel \& Vartia, 2003). Moreover, due to retirements and a growing need of care for the elderly, the municipalities are beginning to find it difficult to recruit enough new staff. This may have aroused a particular interest in taking active steps against bullying, with a view to ensuring a work environment that is not only healthy, but also attractive. As the public sector is often perceived as being more bureaucratic than its private counterpart, this may explain the widespread adoption of formal, written policies. Moreover, as a result of the current structural reforms in the Finnish municipal sector, more is now expected of the municipalities in the way of co-operation. These expectations, and the fact that the municipalities are regarded as being less competitive among themselves, may also have encouraged them to share their own anti-bullying policy documents with each other as well as copying each others’ ideas. 


\section{Conclusion}

The main contribution of the present study has been to provide fresh insights into organizational measures against workplace bullying. Some concern has previously been expressed that researchers and practitioners may be working in isolation from one another in trying to prevent and intervene in bullying (Hoel, Einarsen, Keashly, Zapf \& Cooper, 2003). However, the present study provides some preliminary evidence not only that organizations are starting to make active efforts to prevent workplace bullying, but also that their efforts agree fairly well with recommendations emanating from the research world. Further, it has been found here that the adoption of 'sophisticated' HR practices, negative publicity about bullying and the age of the HR manager, all appear to affect the likelihood of preventive measures being applied.

Moreover, the study found some support for the concern raised by Lewis and Rayner (2003) that the personnel or HR department did not seem to take a very great part in dealing with bullying, beyond formulating policy and initiating training and information. Rather, it was the role of supervisors and immediate superiors that was strongly emphasized in antibullying policy documents, while the role of the HR/personnel department seems to have been limited primarily to prevention rather than intervention.

When it comes to limitations of the study, it should be borne in mind that the response to the survey from the individual municipalities is based on the views of single respondents. Although recipients were asked to pass on the questionnaire to someone else if they did not feel that they were the right person to deal with it, it is possible that not all of the respondents possessed all the relevant information.

Further, we have to remember that the respondents do not necessarily represent all the employers or all the municipalities in Finland. It is very likely that municipalities which had already taken an active interest in working with the issues concerned were also more likely to have responded to this enquiry. Some - albeit weak - support for this assumption emerged when respondents who answered promptly were compared with those who responded only after reminders had been sent. Late responders reported slightly fewer preventive measures, although the difference was not statistically significant. A preliminary study suggested that private companies were less willing to reveal information about anti- 
bullying work (Storgårds, 2006). However, this does not necessarily mean that they take such matters any less seriously. On the contrary, earlier studies have suggested that employees in the private sector feel more strongly than those in the public sector about their organizations' ability to successfully deal with bullying (Salin, 2006).

The present study looks at five aspects of the prevention and monitoring of workplace bullying, namely surveys, written policies, training, information and the statistical reporting of the number of cases found. It should be borne in mind, however, that other aspects connected with job design and internal communications may also be important. Moreover, here only the actual presence or absence of specific measures is considered and it has to be remembered that the importance attaching to their implementation may vary considerably from one organization to another. Although it is often assumed that any action is better than none, Bingham and Scherer (2001) have shown that a badly planned or superficial program against sexual harassment can even have a detrimental and/or counterproductive effect on the attitude of anyone who feels their own position or power to be threatened by such a program. Future studies should thus seek also to analyze the specific content of the various anti-bullying measures more carefully with this type of sensitivity in mind.

Further, while the present study has explored some of the factors that may affect the adoption of preventive measures in organizations, future research should seek to identify further factors that may affect the overall willingness of organizations to take action in this area. The general conflict-management climate, or the safety climate itself, may affect the way managers approach the question of bullying or other inappropriate treatment. Further, as well as simply analyzing the connection between specific 'sophisticated' HR practices and preventive measures, future studies could also look more closely at the relationship between preventive measures and overall sophistication of HR activities, for instance internal and external fit (cf. Huselid, 1995). For private organizations, the specific industrial sector and the organization's degree of internationalization may also be relevant. However, a preliminary study has revealed reluctance among private-sector organizations to discuss bullying, which suggests that it may be necessary to frame the whole issue in more positive terms in order to gain the cooperation of - and access to - the private-sector organizations. 
Finally, this study has also indicated that imitation - rather than genuine organizational necessity - may be a major impetus behind anti-bullying activities. However, we know little about such imitation processes or about the strategies and rationales behind the actors' imitation of each other's actions. Moreover, we know little about the way imitation affects the effectiveness of policies or other possible preventive measures. An important avenue for further research could thus be to study imitation in greater depth - i.e. its processes, rationales and consequences.

\section{Acknowledgements}

The author would like to thank Jeff Hearn and other members of the Research Group on Gender Relations in Organisations, Management and Society at the Swedish School of Economics for helpful and constructive comments in connection with this study. In addition, the author would

like to thank three anonymous reviewers. The study has been funded by the Academy of Finland (decision number 212759). 


\section{References}

Baillien, E., Neyens, I., De Witte, H., \& Vanoirbeek, K. (2005). Ongewenst grensoverschrijdend gedrag op het werk: op welke manier speelt de organisatie een rol? Een kwantitatieve studie van risicofactoren op niveau van job, team en organisatie. Leuven: Onderzoeksgroep voor Stress, Gezondheid en Welzijn.

Bingham, S., \& Scherer, L. (2001). The unexpected effects of a sexual harassment educational program, The Journal of Applied Behavioral Science, 37 (2), 125-153.

Björkqvist, K., Österman, K., \& Lagerspetz, K. (1994). Sex differences in covert aggression among adults, Aggressive Behaviour, 20, 27-33.

Cleveland, J. N., \& Kerst, M. E. (1993). Sexual harassment and perceptions of power: an under-articulated relationship, Journal of Vocational Behavior, 42 (1), 49-67.

Collinson, D. L. (1988). 'Engineering humour': masculinity, joking and conflict in shopfloor relations, Organization Studies, 9 (2), 181-199.

Commission for local authority employees (2007), "Local Authority employees in Finland", Document available at http://www.kuntatyonantajat.fi.

Di Martino, V., Hoel, H., \& Cooper, C. (2003). Preventing Violence and Harassment in the Workplace. European Foundation for the Improvement of Living and Working Conditions. Luxembourg: Office Official Publications of the European Communities.

Edwards, J. \& Bagozzi, R. (2000). On the nature and direction of relationships between constructs and measures, Psychological Methods, 5 (2), 155-174.

Einarsen, S., \& Skogstad, A. (1996). Bullying at work: epidemiological findings in public and private organizations, European Journal of Work and Organizational Psychology, 5 (2), 185-201.

Einarsen, S, Aasland, M., \& Skogstad, A. (2007). Destructive leadership behaviour: A definition and conceptual model, The Leadership Quarterly, 18 (3), 207-216.

Einarsen, S., Raknes, B. I., \& Matthiesen, S. B. (1994). Bullying and harassment at work and their relationships to work environment quality: an exploratory study, European Work and Organizational Psychologist, 4 (4), 381-401.

Einarsen, S., Hoel, H., Zapf D., \& Cooper, C. (2003). The concept of bullying at work: the European tradition. In S. Einarsen, H. Hoel, D. Zapf \& C. Cooper, C (Eds), Bullying and emotional abuse in the workplace: International perspectives in research and practice (pp. 203-218). London: Taylor \& Francis.

European Agency for Safety and Health at Work (2002). Bullying at Work. Fact sheet 23. Available at http://agency.osha.eu.int 
Heffernan, M., \& Flood, P. (2000). An exploration of the relationships between the adoption of managerial competencies, organisational characteristics, human resource sophistication and performance in Irish organisations, Journal of European Industrial Training, 24 (2-4), 128-136.

Hoel, H., \& Cooper, C. L. (2000). Destructive Conflict and Bullying at Work. Manchester: Manchester School of Management, University of Manchester Institute of Science and Technology.

Hoel, H., Einarsen, S., \& Cooper, C. (2003). Organisational effects of bullying. In S. Einarsen, H. Hoel, H., D. Zapf \& C. Cooper, C (Eds), Bullying and emotional abuse in the workplace: International perspectives in research and practice (pp. 145-162). London: Taylor \& Francis.

Hoel, H., Einarsen, S., Keashly, L., Zapf, D., \& Cooper, C. (2003). Bullying at work: the way forward. In S. Einarsen, H. Hoel, D. Zapf \& C. Cooper, C (Eds), Bullying and emotional abuse in the workplace: International perspectives in research and practice (pp. 412-416. London: Taylor \& Francis.

Hubert, A. (2003). To prevent and overcome undesirable interaction: a systematic approach model. In S. Einarsen, H. Hoel, D. Zapf \& C. Cooper, C. (Eds), Bullying and emotional abuse in the workplace: International perspectives in research and practice (pp. 299-311). London: Taylor \& Francis.

Huselid, M. (1995). The impact of human resource management practices on turnover, productivity, and corporate financial performance, The Academy of Management Journal, 38, (3), 635-672.

Lewis, D., \& Rayner, C. (2003). Bullying and human resource management: a wolf in sheep’s clothing? In S. Einarsen, H. Hoel, D. Zapf \& C. Cooper, C (Eds), Bullying and emotional abuse in the workplace: International perspectives in research and practice (pp. 370-382). London: Taylor \& Francis.

MacKenzie, S., Podsakoff, P., \& Jarvis, C. (2005). The problem of measurement model misspecification in behavioral and organizational research and some recommended solutions, Applied Psychology, 90 (4), 710-740.

Mathieson, S., Hanson, M., \& Burns, J. (2006). Reducing the risk of harassment in your organisation. In M. O’Moore, J. Lynch \& M. Smith (Eds), "The Way Forward". Proceedings from the $5^{\text {th }}$ International Conference on Bullying and Harassment in the Workplace (129-131). Dublin: Trinity College.

Mikkelsen, E., \& Einarsen, S. (2002). Relationships between exposure to bullying at work and psychological and psychosomatic health complaints: The role of state negative affectivity and generalized self-efficacy, Scandinavian Journal of Psychology, 43 (5), 397405. 
Moreno-Jiménez, B., Rodríguez-Muñoz, A., Garrosa, E., \& Morante, M.E. (2005). Antecedentes organizacionales del acoso psicológico en el trabajo: un estudio exploratorio, Psicothema, 17, 627-632.

Richards, J., \& Daley, H. (2003). Bullying policy: development, implementation and monitoring. In S. Einarsen, H. Hoel, D. Zapf \& C. Cooper, C (Eds), Bullying and emotional abuse in the workplace: International perspectives in research and practice (pp. 247-258). London: Taylor \& Francis.

Robinson, S. L., \& O'Leary-Kelly, A. M. (1998). Monkey see, monkey do: the influence of work groups on the antisocial behavior of employees, Academy of Management Journal, 41 (6), 658-672.

Salin, D. (2001). Prevalence and forms of bullying among business professionals: A comparison of two different strategies for measuring bullying, European Journal of Work \& Organizational Psychology, 10 (4), 425-441.

Salin, D. (2003). Ways of explaining workplace bullying: enabling, motivating and precipitating structures and processes in the work environment, Human Relations, 56 (10), 1213-1232.

Salin, D. (2006). ¿Se preocupan las organizaciones por el acoso psicológico en el trabajo? Percepciones de los trabajadores sobre las medidas organizacionales contra el acoso psicológico, Revista de Psicología del Trabajo y de las Organizaciones, 22 (3), 413-431.

Salin, D. (2007). The effects of target gender and respondent gender on labelling and explaining workplace bullying, in Proceedings from the $19^{\text {th }}$ Nordic Academy of Management Conference, Bergen, Norway, August 9-11 ${ }^{\text {th }}$, paper available (November 26 ${ }^{\text {th }}, 2007$ ) at http://www.nhh.no/conferences/nff/papers/salin.pdf.

Skogstad, A., Einarsen, S., Torsheim, T., Aasland, M., \& Hetland, H. (2007). The destructiveness of laissez-faire leadership behavior, Journal of Occupational Health Psychology, 12 (1), 80-92.

Storey, J. (1993). The take-up of human resource management by mainstream companies: key lessons from research, International Journal of Human Resource Management, 4 (3), 529-553.

Storgårds, H. (2006). Mobbning på arbetsplatsen: hur förebygger och ingriper organisationer i mobbning [Bullying in the workplace: how do organizations prevent and intervene in bullying?], Unpublished Master's thesis. Helsinki: Swedish School of Economics and Business Administration.

Tepper, B.J. (2000). Consequences of abusive supervision, Academy of Management Journal, 43 (2), 178-190.

Vartia, M. (1996). The sources of bullying - psychological work environment and organizational climate, European Journal of Work and Organizational Psychology, 5 (2), 203-214. 
Vartia, M., Korppoo, L., Fallenius, S., \& Mattila, M-J. (2003). Workplace bullying: the role of occupational health services. In S. Einarsen, H. Hoel, D. Zapf \& C. Cooper, C (Eds), Bullying and emotional abuse in the workplace: International perspectives in research and practice (285-298). London: Taylor \& Francis.

Wall, T., Michie, J., Patterson, M., Wood, S., Sheehan, M., Clegg, C., \& West, M. (2004). On the validity of subjective measures of company performance. Personnel Psychology, 57 (1), 95-118.

Zapf, D. \& Einarsen, S. (2003). Individual antecedents of bullying: victims and perpetrators. In S. Einarsen, H. Hoel, D. Zapf \& C. Cooper, C (Eds), Bullying and emotional abuse in the workplace: International perspectives in research and practice (285298). London: Taylor \& Francis.

Zapf, D., Einarsen, S., Hoel, H. \& Vartia, M. (2003). Empirical findings on bullying in the workplace. In S. Einarsen, H. Hoel, D. Zapf \& C. Cooper, C (Eds), Bullying and emotional abuse in the workplace: International perspectives in research and practice (103-126). London: Taylor \& Francis. 


\section{TABLE 1}

Measures undertaken to prevent and monitor workplace bullying.

\begin{tabular}{|l|r|r|r||}
\hline & \multicolumn{1}{|l|}{ YES } & \multicolumn{1}{l|}{ NO } & $\begin{array}{l}\text { DON'T } \\
\text { KNOW/ NO } \\
\text { RESPONSE }\end{array}$ \\
\hline Written policy & $55.6 \%$ & $34.1 \%$ & $10.3 \%$ \\
\hline Information & $65.9 \%$ & $28.2 \%$ & $5.9 \%$ \\
\hline Bullying surveys & $33.7 \%$ & $60.0 \%$ & $6.3 \%$ \\
\hline Training & $27.3 \%$ & $66.8 \%$ & $5.9 \%$ \\
\hline $\begin{array}{l}\text { Statistical recording of } \\
\text { cases }\end{array}$ & $24.9 \%$ & $68.8 \%$ & $6.3 \%$ \\
\hline
\end{tabular}

$\mathrm{n}=205$ 'Don't know' and lack of response have been grouped together to form the third category. 
TABLE 2

Correlation between number of preventive measures and organizational characteristics

\begin{tabular}{|c|c|c|c|c|c|c|c|}
\hline & $M$ & $S D$ & 1. & 2. & 3. & 4. & 5. \\
\hline $\begin{array}{l}\text { 1. } \begin{array}{l}\text { Number of } \\
\text { preventive } \\
\text { measures }\end{array} \\
\end{array}$ & 2.15 & 1.294 & 1 & $.197^{\star \star}$ & $.361^{\star \star}$ & .098 & $.143^{*}$ \\
\hline $\begin{array}{ll}2 . & \text { Number of } \\
\text { employees }\end{array}$ & 1010 & 3166 & & 1 & $.170^{\star}$ & .085 & -.001 \\
\hline $\begin{array}{ll}3 . & \text { Use of } \\
& \text { sophisticated HR } \\
\text { practices }\end{array}$ & 51.13 & 18.97 & & & 1 & $.221^{\star \star}$ & .036 \\
\hline $\begin{array}{ll}\text { 4. } & \begin{array}{l}\text { Performance of } \\
\text { municipality }\end{array}\end{array}$ & 3.24 & 0.495 & & & & 1 & $-.139 \dagger$ \\
\hline $\begin{array}{l}\text { 5. Negative publicity } \\
\text { concerning } \\
\text { bullying }\end{array}$ & 1.41 & 0.785 & & & & & 1 \\
\hline
\end{tabular}

$\mathrm{n}=155-205,{ }^{*} p<0.01,{ }^{*} p<0.05, \dagger p<0.10$ level 
TABLE 3

Variables used to predict number of preventive measures

Variables in equation

\begin{tabular}{|l|l|l|l|l|l|}
\hline & \multicolumn{2}{|l|}{ Unstandardised Coefficients } & $\begin{array}{l}\text { Standardized } \\
\text { Coefficients }\end{array}$ & t value & $\begin{array}{l}\text { Statistical } \\
\text { significance }\end{array}$ \\
\hline & $B$ & $\begin{array}{l}\text { Standard } \\
\text { Error }\end{array}$ & Beta & & \\
\hline (Constant) & .894 & .359 & & 2.493 & .014 \\
\hline $\begin{array}{l}\text { Use of } \\
\text { soph'. HR } \\
\text { practices }\end{array}$ & .022 & .005 & .335 & 4.239 & .000 \\
\hline $\begin{array}{l}\text { Negative } \\
\text { publicity }\end{array}$ & .260 & .120 & .171 & 2.174 & .031 \\
\hline $\begin{array}{l}\text { Age of HR } \\
\text { manager }\end{array}$ & -.337 & .200 & -.133 & -1.681 & .095 \\
\hline
\end{tabular}

Variables added to regression equation using stepwise multiple regression. $R^{2}=0.168$, adjusted $R^{2}=0.149$. 
FIGURE 1: Disenabling factors acting as a filter in the work environment.

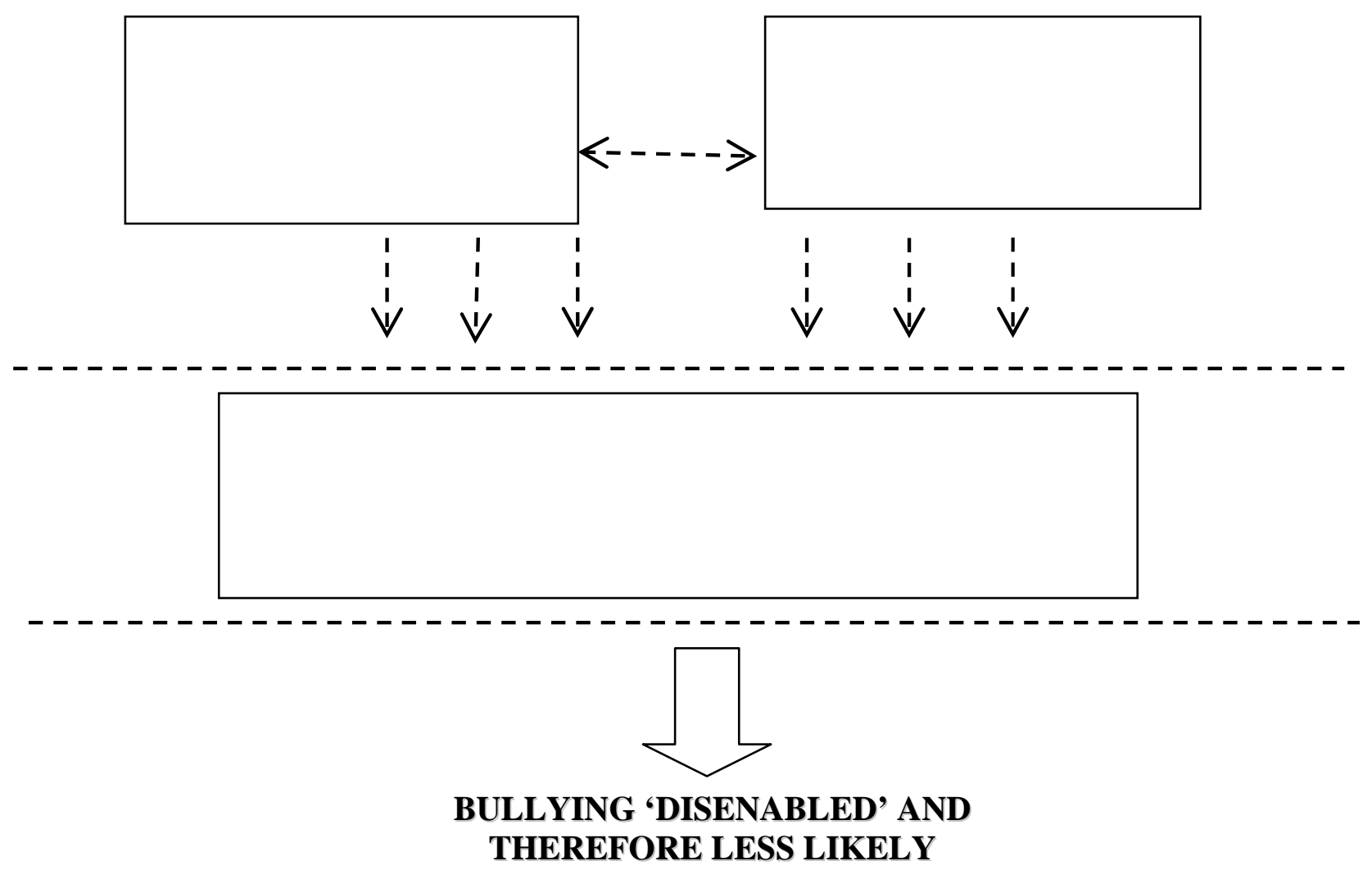

Cf. Salin (2003) on structures and processes that enable, motivate and precipitate bullying. 